\title{
Digestibility and protein utilization responses of soybean and rape seed meal to physical and enzymatic treatments in diets for growing pigs
}

\author{
MATTI NÄSI \\ University of Helsinki Department of Animal Husbandry \\ SF-00710 Helsinki, Finland
}

\begin{abstract}
The effects of extrusion, hydrothermal processing and enzyme pretreatment of soybean meals (SBM) and rapeseed meals (RSM) and the multienzyme supplementation of diets on nutrient digestibility, protein utilization and performance were investigated in growing pigs. The study was comprised of two separate total-collection digestibility and balance trials with $6 \times 6$ Latin square designs and a production trial with 140 growing pigs. The processes employed had only minor effects on the chemical composition of the treated oilseed meals. Extrusion and addition of enzyme premix improved the organic matter $(\mathrm{OM})$ and protein $(\mathrm{CP})$ digestibilities of SBM $(\mathrm{P}<0.05)$. These processes also tended to have a positive effect on the nitrogen retention and protein utilization in the pigs. The hydrothermal process had no effect on the nutritive value of SBM, but improved the OM and CP digestibility in RSM $(\mathrm{P}<0.05)$. Energy values of the treated SBM and RSM tended to increase compared with the untreated meals. There were no significant differences in growth rate, feed conversion or carcase quality between pigs fed diets supplemented with differently treated SBM, relative to untreated control. Partial hydrolysis of the polysaccharides present in SBM and RSM with hydrothermal or enzymatic processing may have resulted in the release of intracellular nutrients in the intestine and improved their absorption and utilization. More consistent responses to these thermal and enzymatic treatments could be expected with younger pigs with less microbial activity in the alimentary canal.
\end{abstract}

Index words: soybean meal, rapeseed meal, processing, enzymes, digestibility, pig

\section{Introduction}

Protein supplementation in pig diets is mainly based on oilseed meals while the use of fish meal is avoided due to its negative effects on meat quality. Proper processing is of great importance in order to ensure the nutritional value of soybean meal (SBM) and rape seed meal (RSM) for pig diets. Heat treatment is necessary to inactivate antinutritional factors present in oilseeds. In soybeans those factors are primarily protease inhibitors and in 
rape seeds glucosinolates, tannins, myrosinase, rapeseed gums and phytic acid. Other processing methods can also enhance the nutritive value of these oil seed meals as an ingredient in pig diets.

Heat treatment and hydrothermal processing rupture the cell wall matrix and modify the chemical structure of plant constituents. These processes render nutrients more susceptible to enzyme degradation in the small intestine, thus improving the digestibility and utilization, especially of amino acids. The content of structural polysaccharides in the soybean is rather low compared with rapeseed, and is mostly present in the hulls, which compose only $7 \%$ of the soybean. The hull fraction in RSM comprises $25-28 \%$ of the dry matter.

The different types of polysaccharides in defatted SBM hulls are galactomannans (9$11 \%)$, acidic polysaccharides (10-12\%), xylan hemicellulose $(9-10 \%)$ and cellulose (40 \%) (Aspinall et al. 1967). The lignin content is low in soybean hulls $(1.3 \%)$, while in rapeseed hulls it is $28.9 \%$ (MITARU et al. 1984). Polysaccharides compose $26 \%$ of hulled SBM and the major components are arabino-galactan and acidic polysaccharides belonging to the pectic group of substances (Aspinall et al. 1967). The polysaccharides present in the greatest amounts in dehulled rapeseed are pectins (14.5\%), cellulose residues $(7 \%)$, and fuco-amyloid, arabinan and arabinogalactan (together 5 to $6 \%$ ) (BELL 1984). Insoluble fibre tends to increase passage rate and to form an insulating coat on the digestible nutrients, thus reducing the nutrient supply. Soluble fibres slow down the transit time, but their gelling, ion-exchange and absorbing characteristics retard digestion and absorption.

The cellulolytic or hemicellulolytic enzymes are potent agents of degradation of poorly digestible or viscous polysaccharides and thus a dietary addition of suitable enzymes (cellulase, $\beta$-glucanase, xylanase, mannase and pectinase) may be of practical importance in improving the feeding value of some low-energy feed components for monogastrics. Enzyme supplementation could also be used to break down anti-nutritional substances found in feed raw materials, thus augmenting the digestive capacity of the animal, improving availability of the nutrients in the feed, and increasing release of nutrients in the upper part of the gastrointestinal tract (CHESSON 1987, DiERICK 1989).

In dry feeding systems, enzymes can be added directly to the complete feed or used in the pretreatment of feeds and feed raw materials. With the former application, the supplementary enzymes will act in the gastrointestinal tract of the pigs. In pretreatment, the enzymes act on specific poorly-digestible substances in the raw material, thus improving its feed value. In wet feeding systems, enzymes can be added directly, and during the soaking they will break down poorly digestible substances. The enzyme mixtures, their composition and the level of activity used depend on the feed composition and the enzymes' stability under feed-processing conditions.

The objective of this study was to elucidate the effect of thermal processing and addition of enzymes or enzymatic pretreatment on the nutritive value of soybean meals. In one of the experiments, rapeseed meals also were processed in the same way as SBM. In addition, a growth trial was performed to investigate the effect of soybean processing and enzyme supplementation on the performance of the pigs. Preliminary results of the present study have been published previously by NÄsI (1988).

\section{Materials and methods}

The animal response to physical and enzymatic treatments of soybean meal and rapeseed meal was evaluated in two digestibility and balance trials and in one performance trial with growing pigs.

The treatments of the soybean meals used in Exp. I. were: 1.) normal solvent-extracted SBM, 2.) SBM extruded with a single-screw extruder, exit temperature ca. $100^{\circ} \mathrm{C}, 3$ ) heattreated, low-degradable SBM for ruminants 
(Öpex-process, Öljynpuristamo Oy, Helsinki), 4.) treatment with multienzyme premix (cellulase, protease and $\beta$-glucanase, Suomen Rehu Oy, Helsinki) addition of $0.1 \%$, in dry solvent-extracted SBM diet, 5.) multienzyme premix added at the level of $0.1 \%$ to a wet SBM diet 8 hours before feeding and 6.) SBM conditioned at $60^{\circ} \mathrm{C}$ and $30 \%$ moisture content, sprayed with enzyme premix $2 \mathrm{~h}$ prior to drying. The chemical composition of the experimental feeds is shown in Table 1.

The treatments of the SBM's and RSM's in Exp. II. were: 1.) normal SBM, 2.) SBM conditioned at $60^{\circ} \mathrm{C}$ and at $30 \%$ moisture for 30 min followed by drying, 3.) SBM treated as above (2.) followed by addition of $0.1 \%$ enzyme (Multienzyme premix, containing cellulase and protease-activities, Suomen Rehu Oy, Helsinki), which was allowed to act for $30 \mathrm{~min}$ prior to drying, 4.) normal RSM, 5.) RSM treated as SBM in 2.), and 6.) RSM treated as SBM in 3), but with an enzyme premix including xylanase and cellobiase as well. The chemical composition of the experimental feeds is presented in Table 2 .

In the first digestibility and balance trial, the variously processed SBM's were used as protein supplements in six isonitrogenous,
$150 \mathrm{~g}$ crude protein $(\mathrm{CP}) / \mathrm{kg}$, barley-based diets. The supplements were fed to growing pigs $(30-75 \mathrm{~kg})$ at the inclusion level of 165 $-185 \mathrm{~g} / \mathrm{kg}$ diet. In the second experiment, three processed SBM's and three RSM's were used as protein supplements in barley-based diets $(160 \mathrm{~g} \mathrm{CP} / \mathrm{kg}$ diet $)$. SBM supplementation was $122-129 \mathrm{~g} / \mathrm{kg}$ diet and that of RSM $185-209 \mathrm{~g} / \mathrm{kg}$. Both experiments had a $6 \times$ 6 Latin square design. The basal diet was evaluated separately. Each period was comprised of 6 days of adjustment and 6 days of faeces and urine total collection. Assay procedures were similar to those reported by NÃsI (1984).

The various SBM's were also evaluated in a performance trial, in which the four diets used had processed SBM as the sole protein supplement. SBM supplementation was $170 \mathrm{~g}$ and the diets contained $130 \mathrm{~g} \mathrm{DCP}$ and $8.7 \mathrm{~g}$ lysine per $\mathrm{kg}$ feed. As a positive control diet a mixture was used in which the protein supplement was $120 \mathrm{~g} \mathrm{SBM}$ and in addition $40 \mathrm{~g} / \mathrm{kg}$ fishmeal $(140 \mathrm{~g} \mathrm{DCP}$ and $9.7 \mathrm{~g} / \mathrm{kg}$ lysine). Pure lysine and methionine were added to adjust the amino acid levels in the rations. The composition of the feeds and their nutrient contents are given in Table 3. The ex-

Table 1. Chemical composition and calculated feed values of the experimental feeds (Experiment. 1).

\begin{tabular}{|c|c|c|c|c|c|c|c|}
\hline \multirow[t]{2}{*}{$\mathrm{g} / \mathrm{kg} \mathrm{DM}$} & \multicolumn{6}{|c|}{ Soybean meals } & \multirow[t]{2}{*}{ Barley } \\
\hline & Normal & $\begin{array}{c}\text { Ex- } \\
\text { truded }\end{array}$ & $\begin{array}{l}\text { Rumen } \\
\text { escape } \\
\text { treated }\end{array}$ & $\begin{array}{c}\text { Enzyme } \\
\text { added } \\
\text { dry }\end{array}$ & $\begin{array}{c}\text { Enzyme } \\
\text { added } \\
\text { wet }\end{array}$ & $\begin{array}{c}\text { Enzyme } \\
\text { pre- } \\
\text { treated }\end{array}$ & \\
\hline Crude protein & 482 & 497 & 508 & 492 & 493 & 493 & 97 \\
\hline Ether extract & 33 & 40 & 31 & 29 & 28 & 28 & 31 \\
\hline Crude fibre & 75 & 73 & 70 & 65 & 65 & 65 & 46 \\
\hline Nitrogen free extract & 347 & 325 & 325 & 352 & 352 & 351 & 804 \\
\hline Neutr. deterg. fibre & 131 & 134 & 134 & 120 & 120 & 123 & 286 \\
\hline Acid deterg. fibre & 93 & 92 & 91 & 81 & 86 & 89 & 64 \\
\hline Lysine, $\mathrm{g} / 160 \mathrm{~g} \mathrm{~N}$ & 62 & 61 & 59 & 62 & 61 & 62 & 41 \\
\hline Threonine " & 40 & 39 & 40 & 41 & 41 & 41 & 35 \\
\hline Methionine " & 15 & 15 & 16 & 17 & 16 & 20 & 19 \\
\hline Cystine $\quad n$ & 17 & 16 & 15 & 17 & 16 & 17 & 24 \\
\hline Available lysine " & 60 & 58 & 56 & 59 & 58 & 58 & 40 \\
\hline FU/kg DM & 1.01 & 1.09 & 1.03 & 1.08 & 1.07 & 1.07 & 1.14 \\
\hline $\mathrm{Kg} / \mathrm{FU}$ & 1.13 & 1.03 & 1.08 & 1.06 & 1.10 & 1.11 & 1.03 \\
\hline DCP, g/kg DM & 394 & 427 & 417 & 426 & 433 & 438 & 68 \\
\hline $\mathrm{ME}, \mathrm{MJ} / \mathrm{kg} \mathrm{DM}$ & 14.77 & 16.01 & 15.14 & 15.86 & 15.75 & 15.79 & 14.71 \\
\hline
\end{tabular}


Table 2. Chemical composition and calculated feed values of the experimental feeds (Experiment. 2).

\begin{tabular}{|c|c|c|c|c|c|c|c|}
\hline \multirow[t]{2}{*}{$\mathrm{g} / \mathrm{kg} \mathrm{DM}$} & \multicolumn{3}{|c|}{ Soybean meals } & \multicolumn{3}{|c|}{ Rapeseed meals } & \multirow[t]{2}{*}{ Barley } \\
\hline & Normal & $\begin{array}{l}\text { Hydro- } \\
\text { thermal } \\
\text { proces. }\end{array}$ & $\begin{array}{c}\text { Enzyme } \\
\text { treat. }\end{array}$ & Normal & $\begin{array}{l}\text { Hydro- } \\
\text { thermal } \\
\text { proces. }\end{array}$ & $\begin{array}{c}\text { Enzyme } \\
\text { treat. }\end{array}$ & \\
\hline Crude protein & 471 & 487 & 494 & 361 & 352 & 349 & 138 \\
\hline Ether extract & 53 & 34 & 32 & 102 & 100 & 98 & 36 \\
\hline Crude fibre & 63 & 77 & 70 & 134 & 123 & 125 & 45 \\
\hline Nitrogen free extract & 303 & 331 & 338 & 329 & 351 & 352 & 758 \\
\hline Neutr. deterg. fibre & 111 & 121 & 101 & 247 & 237 & 235 & 172 \\
\hline Acid deterg. fibre & 57 & 72 & 62 & 182 & 171 & 170 & 41 \\
\hline Acid deterg. lignin & & & & 78 & 73 & 77 & \\
\hline Lysine, g/160 g N & 59 & 60 & 61 & 59 & 57 & 55 & 35 \\
\hline Threonine " & 38 & 39 & 39 & 43 & 45 & 44 & 33 \\
\hline Methionine " & 19 & 15 & 14 & 25 & 24 & 24 & 20 \\
\hline Cystine $\quad "$ & 15 & 16 & 15 & 27 & 25 & 25 & 27 \\
\hline Available lysine " & 56 & 57 & 59 & 56 & 54 & 52 & 34 \\
\hline FU/kg DM & 1.00 & 0.91 & 1.06 & 0.80 & 0.92 & 0.88 & \\
\hline $\mathrm{Kg} / \mathrm{FU}$ & 1.13 & 1.25 & 1.12 & 1.40 & 1.17 & 1.31 & \\
\hline DCP, g/kg DM & 359 & 398 & 368 & 288 & 268 & 272 & \\
\hline $\mathrm{ME}, \mathrm{MJ} / \mathrm{kg} \mathrm{DM}$ & 14.8 & 13.6 & 15.7 & 12.0 & 13.7 & 13.0 & \\
\hline
\end{tabular}

perimental animals numbered 140 , seven replicates of four pigs being used in each treatment. The pigs were assigned at random to the different feeds, with the variation in starting weight between the groups kept as small as possible. The pigs were weighed every two weeks and and the feed consumption was determined for each pen. Feeding was made according to the weight-based schedule of SALO et al. (1982). The individual pigs were slaughtered at an average weight of $100 \mathrm{~kg}$, at which time the carcase weight was recorded and the carcase classified.

\section{Results and discussion}

Only small differences were found in the proximate composition of the processed SBM's. Enzyme-treated SBM had slightly lower crude fibre, NDF and ADF than normal or extruded SBM. However the differences were quite small. The different SBM's were similar in their amino acid composition except that the SBM treated for ruminants had a lower lysine and available lysine content. Small reductions in lysine were also evident in other processed SBM's (Table 1). Excessive heat treatment during processing can lead to the destruction of amino acids and the formation of biologically unavailable amino acid carbohydrate complexes such as Maillard reaction products (MAURON 1981). Total lysine may be lost during heating but available lysine is depressed even more (ROACH et al. 1967). Veltman et al. (1986) have shown that increased cooking temperature reduces $\mathrm{CP}$ content of a SBM treated for rumen escape and decreases amino acids such as lysine, methionine and threonine.

In Expt. II processing did not have any effect on the fibre composition of SBM's and only a small reduction was noticed in the NDF and ADF content of treated RSM's (Table 2). Processing reduced the lysine content and availability in RSM's. According to the data of INBORR et al. (1988), hydrothermal and enzymatic processing decreased the content of lysine and available lysine in barley meal. The same observation was made for processed oats by NÄsı (1988, unpublished data) when methods of processing similar to the present experiments were applied. The processing conditions should be optimal for the action of the enzymes, but at the same time care has to be 
Table 3. Chemical composition and calculated feed values of the experimental feeds (Experiment. 3).

\begin{tabular}{|c|c|c|c|c|c|}
\hline \multirow[t]{2}{*}{$\mathrm{g} / \mathrm{kg} \mathrm{DM}$} & \multirow{2}{*}{$\begin{array}{l}\text { Contr. } \\
\text { posit. }\end{array}$} & \multicolumn{4}{|c|}{ Soybean meals } \\
\hline & & Normal & $\begin{array}{l}\text { Rumen } \\
\text { escape } \\
\text { treated }\end{array}$ & Extruded & $\begin{array}{c}\text { Extruded } \\
\text { Enzyme- } \\
\text { pretreated }\end{array}$ \\
\hline \multicolumn{6}{|l|}{ Ingredients, $\mathrm{g} / \mathrm{kg}$} \\
\hline Barley & 717 & 707 & 701 & 699 & 690 \\
\hline Oats & 50 & 50 & 50 & 50 & 50 \\
\hline Molasses & 20 & 20 & 20 & 20 & 20 \\
\hline \multicolumn{6}{|l|}{ Soybean meal } \\
\hline normal & 117 & 161 & & & \\
\hline rumen escape (Öpex) & & & 167 & & \\
\hline extruded & & & & 169 & \\
\hline extruded, enzyme pret. & & & & & 178 \\
\hline Fishmeal & 40 & & & & \\
\hline Skimmilk powder & 10 & & & & \\
\hline Fat mixture & 10 & 20 & 20 & 20 & 20 \\
\hline L-lysine & 1.0 & 1.2 & 1.2 & 1.2 & 1.2 \\
\hline DL-methionine & 0.3 & 0.3 & 0.3 & 0.3 & 0.3 \\
\hline Mineral + vitamin prem. & 35 & 35 & 35 & 35 & 35 \\
\hline \multicolumn{6}{|l|}{ Calculated nurtients } \\
\hline Digestible CP, g/kg & 140 & 129 & 129 & 129 & 129 \\
\hline FU/kg feed & 1.00 & 1.00 & 1.00 & 1.00 & 1.00 \\
\hline Lysine, $\mathrm{g} / \mathrm{kg}$ & 9.7 & 8.7 & 8.7 & 8.7 & 8.7 \\
\hline Meth. + cyst., g/kg & 6.2 & 5.6 & 5.6 & 5.6 & 5.6 \\
\hline Threonine, $\mathrm{g} / \mathrm{kg}$ & 6.3 & 5.8 & 5.8 & 5.8 & 5.8 \\
\hline Calcium, $\mathrm{g} / \mathrm{kg}$ & 9.0 & 9.0 & 9.0 & 9.0 & 9.0 \\
\hline \multicolumn{6}{|c|}{ Analysed composition, g/ $\mathrm{kg} \mathrm{DM}$} \\
\hline Dry matter & 886 & 892 & 886 & 890 & 889 \\
\hline Ash & 57 & 57 & 57 & 56 & 57 \\
\hline Crude protein & 186 & 171 & 170 & 169 & 170 \\
\hline Ether extract & 37 & 45 & 44 & 46 & 45 \\
\hline Crude fibre & 53 & 52 & 56 & 57 & 57 \\
\hline Nitrogen free extract & 666 & 675 & 673 & 671 & 671 \\
\hline
\end{tabular}

Table 4. Digestibilities of processed soybean meals and protein utilization of the diets (Experiment 1).

\begin{tabular}{lcccccccc}
\hline & \multicolumn{9}{c}{ Soybean meals } & SEM & $\begin{array}{c}\text { Statis. } \\
\text { signif. }\end{array}$ \\
\cline { 2 - 7 } & Normal & $\begin{array}{c}\text { Ex- } \\
\text { truded }\end{array}$ & $\begin{array}{c}\text { Rumen } \\
\text { escape } \\
\text { treated }\end{array}$ & $\begin{array}{c}\text { Enzyme } \\
\text { added } \\
\text { dry }\end{array}$ & $\begin{array}{c}\text { Enzyme } \\
\text { added } \\
\text { wet }\end{array}$ & $\begin{array}{c}\text { Enzyme- } \\
\text { pretreat. }\end{array}$ & \\
\hline Organic matter & 0.795 & 0.851 & 0.801 & 0.851 & 0.837 & 0.864 & 0.027 & NS \\
Crude protein & 0.817 & 0.860 & 0.821 & 0.865 & 0.879 & 0.887 & 0.017 & $*$ \\
Ether extract & 0.497 & 0.708 & 0.642 & 0.649 & 0.704 & 0.735 & 0.103 & NS \\
Crude fibre & 0.415 & 0.522 & 0.425 & 0.393 & 0.422 & 0.355 & 0.072 & NS \\
Nitrogen free extract & 0.876 & 0.927 & 0.891 & 0.930 & 0.874 & 0.875 & 0.037 & NS \\
N intake, g/d & 47.1 & 48.3 & 47.6 & 47.9 & 47.9 & 48.8 & 0.321 & NS \\
N excr. in faeces, g/d & 10.9 & 10.1 & 10.9 & 10.1 & 9.7 & 9.7 & 0.408 & $*$ \\
N excr. in urine, g/d & 16.2 & 17.2 & 16.8 & 17.1 & 17.6 & 17.6 & 0.492 & NS \\
N retained, g/d & 20.0 & 20.9 & 19.9 & 19.9 & 20.5 & 21.5 & 0.713 & NS \\
$\quad$ of intake & 0.425 & 0.437 & 0.423 & 0.423 & 0.430 & 0.448 & 0.022 & NS \\
$\quad$ of absorbed & 0.561 & 0.559 & 0.558 & 0.538 & 0.542 & 0.561 & 0.022 & NS \\
UreaN excr. in urine, g/d & 17.2 & 14.8 & 14.8 & 20.3 & 17.6 & 17.3 & 0.637 & NS \\
Biological value & 0.643 & 0.638 & 0.639 & 0.618 & 0.621 & 0.637 & 0.013 & NS \\
\hline
\end{tabular}

$\mathrm{SEM}=$ standard error of the means; significance: NS (non-significant), ${ }^{*}(\mathrm{P}<0.05),{ }^{* *}(\mathrm{P}<0.01)$. 
taken to avoid destruction of amino acids and their availability.

The digestibility of $\mathrm{CP}$ in the different SBM's varied from 0.817 to 0.887 , and differed significantly between untreated and enzyme-pretreated SBM $(\mathrm{P}<0.05)$. Addition of enzyme to the diet or extrusion of SBM tended to improve both $\mathrm{OM}$ and $\mathrm{CP}$ digestibility (Table 4). Enzymatic processing also improved the OM and ether extract digestibility of SBM $(\mathrm{P}<0.05)$ in Exp. II, but not of RSM, while hydrothermal processing of RSM increased $\mathrm{OM}$ and $\mathrm{CP}$ digestibility $(\mathrm{P}<0.05$, Table 5). SBM treated for ruminants in order to decrease protein degradability had the same digestibility as normal SBM. This has practical importance, since the same lots of oil seed meals can be used for both ruminants and monogastrics. Addition of enzyme, wet feeding and pretreatment of SBM resulted in higher mean nitrogen retention than diets with other SBM but differences were not significant ( $\mathrm{P}>0.05$, Table 4). It is also possible that the addition of enzyme to SBM in wet feeding can have an effect on the barley in the diet and that this is partly responsible for the improved nutrient utilization. A small improvement is achieved by enzyme, mainly $\beta$-glucanase, supplements in barley-based diets (GRAHAM et al. 1986, InBORR et al. 1988, THACKer et al. 1988). Acid resistance of the enzyme supplements in applying direct addition in diet is of great importance because in pig stomach there is very low $\mathrm{pH}$.

It has been well established that the nutritive value of vegetable protein is improved by heat treatment. Industrial applications of heat treatment for feeds are extrusion, toasting, pressure cooking and infrared radiation. With some exceptions heat treatment may result in an increased accessibility of protein to enzymatic attack (VAN DeR Pol 1990). Heating primarily inactivates the proteinaceous antinutritive factors in oilseed meals. Improved energy values of the processed oilseed meals found in present study are in agreement with previous studies, in that extrusion has been found to improve organic matter and energy digestibility of grain or grain, SBM and wheat middlings diets (Noland et al. 1976, SкосH et al. 1983, Fadel et al. 1988, Herkelman et al. 1990).

No affect on the utilization of protein or lysine at the terminal ileum was observed in the study of Herkelman et al. (1990), while Noland et al. (1976) reported improved protein digestibility following by extrusion in agreement with the present observations. Present finding that enzyme pretreatment of meals and hydrothermal processing of RSM improved ADF and NDF digestibilities is supported by the higher NDF digestibility noticed after pressure cooking (V DEN POL et al. 1989). Extrusion or other hydrothermal processes have also resulted in 0.19 more ileal digestion of soluble non-starch polysaccharides (NSP) and 0.13 more lower tract digestion of insoluble NSP (FADEL et al. 1988).

In this study a mixture of enzymes having several activities was used, while the response of pigs to supplementation of diets with proteolytic enzymes alone has been very poor (review of Dierick (1989). Only in baby pigs did proteolytic enzymes improve live weight gain and feed conversion (LEwIS et al. 1955, BAKER et al. 1956). However, Zamora and Veum (1979) found that growing pigs have a greater growth rate and net nitrogen utilization due to improved amino acid availability when heated whole soybeans fermented with some fungi were fed compared with heated unfermented whole soybeans.

Pigs do not secrete endogenous enzymes which break down NSP found in most raw materials of plant origin. Degradation of the cell wall matrix and the structural polysaccharides in rapeseed fibre by physical or other means promotes the release of intracellular nutrients in the small intestine for digestion and absorption. The addition of enzyme preparations with cellulolytic and hemicellulolytic activities has improved feed utilization in pigs, but the results have not always been consistent (review of DIERICK 1989). Recently improvements in performance were noted when diets for early-weaned pigs were supplement- 


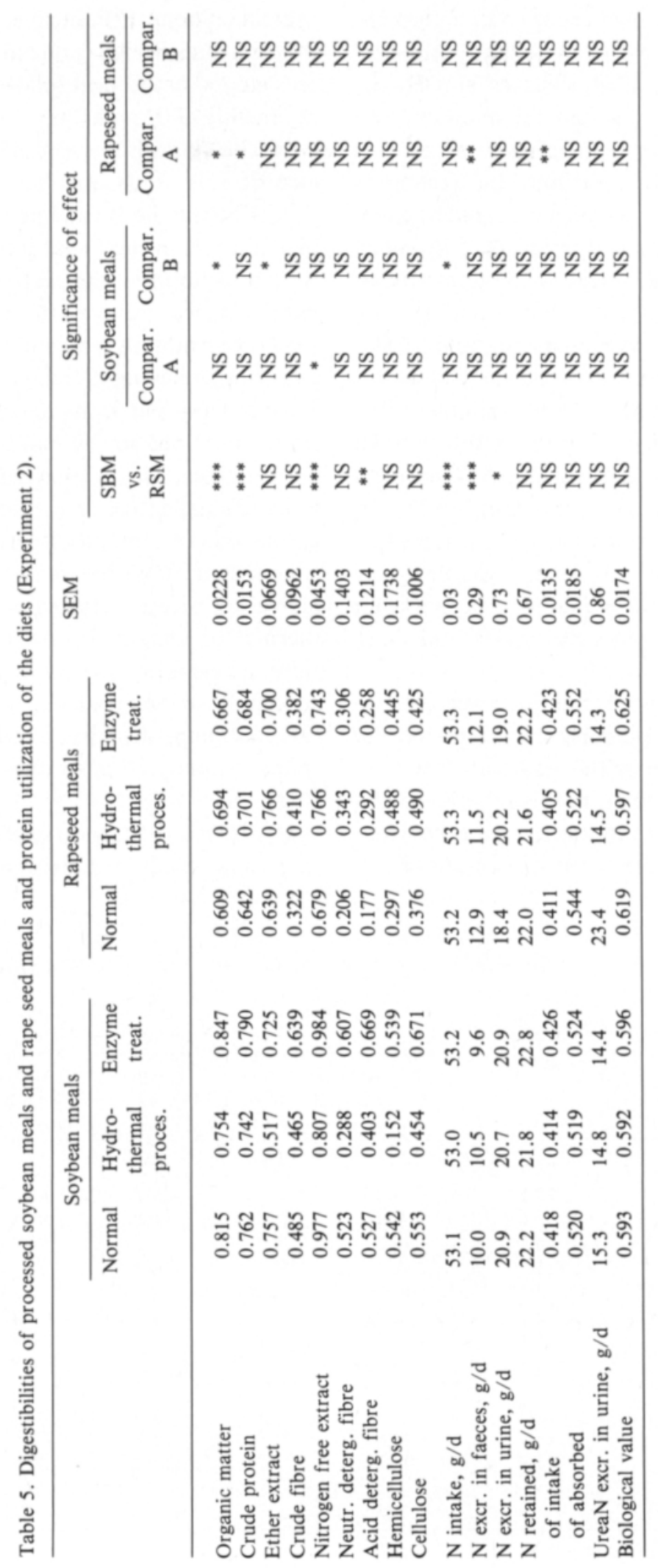


ed with enzyme preparations containing amylase, proteases, $\beta$-glucanase and cellulases (Hogeberg et al. 1983, Collier and Hardy $1986 \mathrm{a}, \mathrm{b})$, indicating that the animals' own digestive enzyme system seems to be limiting in some way. Some antinutritive factors as glucosinolates in rapeseed meal could be eliminated with enzymatic treatments followed by fermentation as reported by STARON (1984). Dense populations of cellulolytic and pectinolytic anaerobes have been measured in the intestines of pigs fed different diets (CHESSON et al. 1985). This suggests that bacterial fibredegrading capacity in growing pigs may be sufficient to degrade reasonable NSP enabling proper digestion. A component of the response to the treatments may be affected by the age of the experimental pigs. Probably treatment responses would have been greater in piglets as indicated by INBORR and OGLE (1988).

In the performance trial there were no significant effects of dietary treatments on the average daily gain or the feed conversion ratio $(P>0.05$, Table 6). In this experiment the positive control group was fed a diet containing fish meal protein supplement and a higher protein content. Fish meal is now avoided in the diets of growing pig due to offflavor which are detected in the meat followed by lower eating quality. Formulas have been made using only oilseed meals to supplement protein. The aim of this study was to elucidate which processing methods can improve the value of oilseed meal in pig diets. Extrusion of SBM tended to improve the performance as compared with the group on the normal SBM and gave the same daily gain and FCR as the positive control having a greater protein supply. This observation is in agreement with the results obtained in the balance trial. In this performance test the enzymatic process had a rather small effect, in contrast to the results obtained in the digestibility trial, but it is possible that during preparation of the feed inactivation of the enzymes occurred. Hydrothermal or enzymatic treatments of barley fibre, a by-product with a high hemicellulose content from intergraded starch-ethanol process, containing diets for growing pigs did not result in improved performance in an earlier study (NÄSI 1989).

Hydrolysis of structural plant polysaccharides is generally of nutritional benefit. The

Table 6. Performance of pigs on diets supplemented with soybean meals processed with different methods (Experiment. 3).

\begin{tabular}{|c|c|c|c|c|c|c|}
\hline & \multirow{2}{*}{$\begin{array}{l}\text { Contr. } \\
\text { posit. }\end{array}$} & \multicolumn{4}{|c|}{ Soybean meals } & \multirow{2}{*}{$\begin{array}{l}\text { Statist } \\
\text { signif. }\end{array}$} \\
\hline & & Normal & $\begin{array}{l}\text { Rumen } \\
\text { escape } \\
\text { treated }\end{array}$ & Extruded & $\begin{array}{l}\text { Extruded } \\
\text { Enzyme- } \\
\text { pretreated }\end{array}$ & \\
\hline No. pigs in test & 28 & 27 & 25 & 28 & 28 & NS \\
\hline Initial liveweight, $\mathrm{kg}$ & 29.5 & 29.2 & 29.5 & 29.5 & 29.5 & NS \\
\hline Final liveweight, kg & 99.6 & 97.4 & 98.7 & 100.3 & 98.5 & NS \\
\hline Days in test & 86.8 & 90.0 & 90.5 & 88.2 & 88.8 & NS \\
\hline Daily gain, $\mathrm{g}$ & 815 & 762 & 766 & 807 & 781 & NS \\
\hline Feed intake, kg/d & 2.32 & 2.26 & 2.26 & 2.29 & 2.25 & NS \\
\hline Feed/gain, kg/kg LWG & 2.87 & 2.99 & 2.95 & 2.85 & 2.90 & NS \\
\hline Carcase weight, kg & 71.1 & 69.4 & 70.0 & 71.4 & 70.1 & NS \\
\hline Dressing & 0.714 & 0.712 & 0.710 & 0.712 & 0.711 & NS \\
\hline \multicolumn{7}{|l|}{ Carcase grading, $\%$} \\
\hline $\mathrm{E}+$ glass & 22.2 & 18.5 & 16.0 & 21.4 & 21.4 & \\
\hline $\mathrm{E}$ & 25.9 & 29.6 & 32.0 & 21.4 & 28.6 & \\
\hline I & 51.9 & 48.2 & 52.0 & 57.2 & 46.4 & \\
\hline $\mathrm{I}-$ & & & & & 3.6 & \\
\hline Withdrawal & & 3.6 & & & & \\
\hline
\end{tabular}

See footnote Table 4. 
breakdown of the cell walls makes nutrients available which would otherwise be protected from digestive processes. Legume seeds contain specific gel-forming polysaccharides and the destruction of these polysaccharides by hydrothermal processing or the application of enzymes tended to give better performance than feeding untreated material in this study.

Endo-enzymes produce random hydrolysis of linkages within a polysaccharide chain. Cleavage of relatively few linkages rapidly leads to chain shortening and subsequent loss of gel-forming properties (CHESSON 1987). FEKETE (1984) has suggested that the greatest benefit from the addition of cellulase to pig diets is an improvement in nitrogen utilization rather than enhanced utilization of fibre.

\section{References}

Aspinall, G.O., Bergie, R. \& McKay, J.E. 1967. Polysaccharide components of soybeans. Cereal Sci. Today 12: 223-228, 260-261.

Baker, R.O., Lewis, C.J., Wilbur, R.W., Hartman, P.A., Speer, V.C., Ashton, G.C. \& Gatron, D.V. 1956. Supplementation of baby pig diets with enzymes. J. Anim. Sci. 15: 1245.

Bell, J.M. 1984. Nutrients and toxicants in rapeseed meal: A review. J. Anim. Sci. 58: 996-1010.

CHEsson, A. 1987. Supplementary enzymes to improve the utilization of pig and poultry diets. In Recent advances in animal nutrition. Eds. W. Haresign \& D.J.A Cole. p. 71-91. Butterworths, Oxford. U K.

-, Richardson, A. \& Robertson, J.A. 1985. Fibre digestion and bacteriology of the digestive tract of pigs fed cereal and vegetable fibre. In Digestive physiology in the pig. Eds. Just, A, Jorgensen, H. and Fernandez, J.A Rep. 580: 272-275. Copenhagen.

Collier, B. \& Hardy, B. 1976 a. The use of enzymes in pig and poultry feeds I. Feed Compounder 6: 14-19.

-, \& HARDY, B. 1976 b. The use of enzymes in pig and poultry feeds II. Feed Compounder 6: 28-30.

Dierick, N.A. 1989. Biotechnology aids to improve feed and feed digestion: enzymes and fermentation. Arch. Anim. Nutr. 39: 241-261.

Fadel, J.G., Newman, W.C., Newman, R.K. \& Graham, H. 1988. Effects of extrusion cooking of barley on ileal and fecal digestibilities of dietary components in pigs. Can. J. Anim. Sci. 68: 891-897.

FeKetE, L. 1984. Ref Chesson, A. 1987.

Graham, H., Hesselman, K, Jonsson, E. \& Ảman, P.
When only one enzyme activity is added to the diet, the structural polysaccharides in the plant cell wall may remain intact. A multienzyme additive with cellulolytic and proteolytic activities can degrade the polysaccharides more effectively, promoting release of intracellular nutrients in the small intestine for digestion and absorption. This may be more important in younger pigs than those used in the present experiment, since the oligosaccharides, especially raffinose and stachyose of SBM have been reported to cause diarrhea in young pigs.

Acknowledgements. Thanks are due to Mr. Heikki Hassinen, M. Agr Sc. and Ms. Anna Pajanen for technical assistance. The financial support of Cultor Ltd. is gratefully acknowledged.
1986. Influence of $\beta$-glucanase supplementation on digestion of a barley-based diet in the pig gastrointestinal tract. Nutr. Rep. Intern. 34: 1089-1096.

Herkelman, K.L., Rodhouse, S.L., Veum, T.L. \& EllerSIECK, M.R. 1990. Effect of extrusion on the ileal and fecal digestibilities of lysine in yellow corn in diets for young pigs. J. Anim. Sci. 68: 2414-2424.

Hogeberg, M., Shurson, G., Horrocks, S. \& Haines, S. 1983. Research Report 456. Michigan State University.

INBORR, J., NĀsı, M. \& SuOMI, K. 1988. The effect of enzyme treatment of cooked barley and supplementation of piglet diets on digestibility of barley and piglet performance. J. Agric. Sci. Finl. 60: 685-699.

- \& Ogle, R.B. 1988. Effect of enzyme treatment of piglet feeds on performance and postweaning diarrhoea. Swed. J. Agric. Res. 18: 129-133.

Lewis, C., Catron, D., Liu, G., Speer, K. \& Ashton, G. 1966. J. Agric. Food. Chem. 3: 1047.

Mauron, J. 1981. Maillard reaction in food. A critical review from nutritional standpoint. Prog. Food \& Nutr. Sci. 5: 5-35.

Mitaru, B.N., Blair, R., Reichart, R.D. \& Roe, W.E. 1984. Dark and yellow rapeseed hulls, soybean hulls and purified fiber source: their effects on dry matter, energy, protein and amino acid digestibilities in cannulated pigs. J. Anim. Sci. 59: 1510-1518.

Noland, P.R., Campbell, D.R., Gage, R.K, Sharp, R.N. \& Johnson, Z.B. 1976. Evaluation of processed soybeans and grains in diets for young pigs. J. Anim. Sci. 43: 763-769. 
NĂSI, M. 1984. Nutritive value and metabolic effects of whey protein concentrate and hydrolysed lactose for growing pigs. J. Agric. Sci. Finl. 56: 221-226.

- 1988. Effects of physical and enzymatic treatments on digestibility and protein utilization of soybean meal in diets for growing pigs. Proc. 4th Int. Sem. Digestive physiology in the pig. Polish Academy of Sciences. p. 381-388. Jablonna.

- 1989. Barley feed fractions from integrated ethanolstarch process in diets of pigs. J. Agric. Sci. Finl. 61: 441-450.

Roach, A.G., Sanderson, P. \& Williams, D.R. 1967. Comparison of methods for the detemination of available lysine value in animal and vegetable protein sources. J. Sci. Food Agric. 18: 274-278.

Salo, M-L., Tuori, M. \& Kinskinen, T. 1982. Rehutaulukot ja ruokintanormit. Helsinki.

Skoch, E.R., Binder, S.F., Deyoe, C.E., Allee, G.L. \& BEHNKE, K.C. 1983. Effects of steam pelleting conditions and extrusion cooking on a swine diet containing wheat middlings. J. Anim. Sci. 57: 929-935.

Staron, T. 1974. Aliment. Vie. 62: 165. Ref. Dierick, N. A. (1989).

\section{SELOSTUS}

\section{Lämpö- ja entsyymikäsittelyjen vaikutus soija- ja rypsirouheen rehuarvoon lihasikojen ruokinnassa}

\section{Matti Näsi \\ Helsingin yliopisto, kotielaintieteen laitos 00710 Helsinki}

Tutkimuksessa selvitettiin erilaisten lämpö- ja entsyymikäsittelyjen sekă entsyymilisäysten vaikutusta soija- ja rypsirouheiden rehuarvoihin ja valkuaisen hyvăksikäyttöoon lihasikojen ruokinnassa. Tutkimus kăsitti kaksi sulavuus- ja tasekoetta $(6 \times 6$ latinalaiset neliöt $)$ sekă tuotantokokeen, jossa oli 140 lihasikaa. Rouheiden prosessointeina oli ekstrudointi, kostea lämpőkäsittely ja entsymaattinen käsittely. Entsyymiseosta lisăttiin myős kăsittelemăttơmaaăn soijarouheeseen sikojen ruokinnan yhteydessä joko kuivaan rehuun tai 12 tuntia ennen ruokintaa kostutettuun soijarouheeseen. Ekstrudointi ja entsyymikäsittely paransivat soijarouheen orgaanisen aineen ja
Thacker, P.A., Campbell, G.L. \& Grootwassink, J.W.D. 1988. The effect of $\beta$-glucanase supplementation on the performance of pigs fed hull-less barley. Nutr. Rep. Intern. 38: 91-99.

Van Der Poel, A.F.B., Den Hartog, L.A, Van Der Abeele, TH., Boer, H. \& VAn Zuilichem, D.J. 1989. Effect of infrared irradiation or extrusion processing of maize on its digestibility in piglets. Anim. Feed Sci. Technol. 26: 29-43.

- 1990. Effects of processing on antinutritional factors and protein nutritional value of dry beans (Phaseolus vulgaris L.). A review. Anim. Feed Sci. Technol. 29: 179-208.

Veltmann, J.R., Hansen, B.C., Tanksley, T.D., Knabe, D. \& Linton, S.S. 1986. Comparison of nutritive value of different heat-treated commercial soybean meals: utilization by chickens in practical type rations. Poult. Sci. 65: 1561-1570.

Zamora, R. \& Veum, T. 1979. Whole soybeans fermented with Aspergillus oryzae and Rhizopus oligosporus for growing pigs. J. Anim. Sci. 48: 63-68.

Ms received December 18, 1990

raakavalkuaisen sulavuutta. Lämpökäsittely lisäsi rypsirouheen sulavuutta. Käsittelyt lisäsivät myös hieman valkuaisen hyvăksikäyttőă sekă laskennallista energia-arvoa. Tuotantokokeessa eri tavoin käsitellyt soijarouheet eivăt poikenneet merkitsevästi käsittelemättömästă, ekstrudoinnin ollessa kuitenkin toisia parempi. Saatujen tulosten perusteella sekä fysikaalisilla ettă entsymaattisilla kăsittelyillă oli rouheiden kăyttőkelpoisuutta parantava vaikutus sikojen ruokinnassa. Vaikutus perustui ilmeisesti kuituaineksen ja solunseinämien pilkkoutumiseen ja sită kautta ravintoaineiden parantuneeseen sulavuuteen ja imeytymiseen. 